\title{
Rationale for anti-inflammatory therapy in dry eye syndrome
}

\author{
Bases da terapia antiinflamatória em síndrome do olho seco
}

\author{
De Paiva CS ${ }^{1}$ \\ Pflugfielder SC ${ }^{2}$
}

\begin{tabular}{|l|}
\hline ABSTRACT \\
\hline Dry eye is a multifactorial condition that results in a dysfunctional \\
lacrimal functional unit. Evidence suggests that inflammation is involved \\
in the pathogenesis of the disease. Changes in tear composition including \\
increased cytokines, chemokines, metalloproteinases and the number of \\
$\mathrm{T}$ cells in the conjunctiva are found in dry eye patients and in animal \\
models. This inflammation is responsible in part for the irritation symp- \\
toms, ocular surface epithelial disease, and altered corneal epithelial \\
barrier function in dry eye. There are several anti-inflammatory therapies \\
for dry eye that target one or more of the inflammatory mediators/path- \\
ways that have been identified and are discussed in detail.
\end{tabular}

Keywords: Dry eye syndromes; Inflammation, Concentration /osmolar; Cyclosporine/therapeutic use, Doxycycline/therapeutic use; Cytokines/therapeutic use; Metalloproteases; Anti-Inflammatory agents/therapeutic use

\section{Inflammation in dry eye}

Dry eye is the second most common problem of patients seeking eye care, and is characterized by eye irritation symptoms, blurred and fluctuating vision, tear film instability, increased tear osmolarity and ocular surface epithelial disease ${ }^{(1-4)}$. It is often a challenging clinical problem to identify because of its varying clinical presentation. Dry eye impacts quality of life by decreasing functional vision, i.e. the ability to perform daily activities such as reading, using a computer and driving ${ }^{(5)}$.

There is an increasing evidence that dry eye is an inflammatory disease. Disease or dysfunction of the tear secretory glands leads to changes in tear composition, such as hyperosmolarity that stimulate the production of inflammatory mediators on the ocular surface ${ }^{(6)}$. Inflammation may in turn cause dysfunction or disappearance of cells responsible for tear secretion or retention ${ }^{(7)}$. Inflammation can also be initiated by chronic irritative stress (e.g. contact lenses) and systemic inflammatory/autoimmune disease (e.g. rheumatoid arthritis). Regardless of the initiating cause, a vicious cycle of inflammation may develop on the ocular surface in dry eye that leads to ocular surface disease. This review will focus on some of the recent findings/evidences about dry eye and inflammation.

\section{Increased inflammatory cytokines}

Increased production and activation of pro-inflammatory cytokines (interleukin [IL]-1 and tumor necrosis factor [TNF]- $\alpha$ ) and proteolytic enzymes by stressed ocular surface and glandular epithelial cells, as well as by the inflammatory cells that infiltrate these tissues have been reported in dry eye $\mathrm{e}^{(8-10)}$.

Increased concentration of pro-inflammatory cytokines and chemokines in the tear fluid, such as IL-6, IL-1, TNF- $\alpha$ has been extensively reported ${ }^{(7,11-18)}$. 
Experimental dryness significantly increased the expression of IL- $1 \alpha$, IL-6, and TNF- $\alpha$ transcripts in the corneal epithelium and conjunctiva of C57BL/6 mice ${ }^{(19)}$.

In humans, significantly increased levels of IL-1 $\alpha$, IL-6, IL- 8, TNF- $\alpha$ and transforming growth factor (TGF)- $\beta 1$ RNA transcripts have been found in the conjunctival epithelium of Sjögren's syndrome, the most severe type of dry eye, compared to controls ${ }^{(12)}$. However, the exact role of these cytokines in dry eye have not been fully elucidated.

\section{Tear film osmolarity}

Hyperosmolarity of the tear fluid has been recognized for decades as a common feature of all types of dry eye and it has been referred to as the "gold standard" for the diagnosis of dry eye $\mathrm{e}^{(20)}$. It is also recognized as a pro-inflammatory stimulus $^{(21-22)}$. Exposure of cultured corneal epithelial cells to media of increasing sodium chloride concentration results in a concentration dependent increase in the production of the same pro-inflammatory factors that have been detected in the conjunctival epithelium and tear fluid of dry eye patients (i.e. IL-1, IL-8, TNF- $\alpha$, and MMP-9) ${ }^{(23-24)}$. In vivo and in vitro, hyperosmolarity was shown to stimulate the production of these inflammatory mediators by activating mitogen activated protein kinases ${ }^{(6,24-25)}$.

\section{Increased metallproteinases}

Another pathologic change is an increased concentration and activity of matrix metalloproteinases (MMPs) in the tear fluid of dry eye patients ${ }^{(13,26-27)}$. These enzymes, such as MMP-9, lyse a variety of different substrates including components of the corneal epithelial basement membrane and tight junction proteins (such as ZO-1 and occludin) that maintain corneal epithelial barrier function ${ }^{(28-29)}$. In a group of dry eye patients, we observed that tear MMP-9 activity levels increased as the severity of corneal disease progressed. Tear MMP-9 activity levels also correlated positively with corneal fluorescein staining scores and with low contrast visual acuity ${ }^{(30)}$.

MMP-9 appears to play a physiological role in regulating corneal epithelial desquamation. In systemic vitamin A deficiency, there is reduced expression of MMP-9 and hyperstratification of the corneal epithelium. In contrast, the increased MMP-9 activity in keratoconjunctivitis sicca (KCS) is associated with deranged corneal epithelial barrier function (increased fluorescein permeability), increased corneal epithelial desquamation (punctate epithelial erosions) and corneal surface irregularity ${ }^{(6,28-29)}$.

\section{Chemokines and chemokine receptors}

Chemokines are small peptides that can induce recruitment of nearby responsive cells. They are important in sites of inflammation because they can amplify the cascade by attracting more and more inflammatory cells.

In human cystic fibrosis patients, the tear levels of the chemokine macrophage inflammatory protein $1 \alpha$ (MIP-1 $\alpha$ ) were significantly higher when compared with healthy controls and correlated with dry eye findings in these patients ${ }^{(31)}$.

In an animal experimental dry eye model, desiccating stress significantly increased concentrations of MIP- $1 \alpha$, MIP-1 $\beta$, monokine induced by interferon (MIG)-gamma, and interferon-gamma-inducible protein (IP)-10 proteins in the corneal epithelium and conjunctiva of C57BL/6 mice $^{(32)}$.

\section{Inflammatory cascade and immune system}

The increase in soluble and cellular inflammatory mediators in the tear fluid, conjunctiva and lacrimal glands initiates an inflammatory cascade on the ocular surface, evidenced by increased expression of immune activation and adhesion molecules (HLA-DR and ICAM-1) by the conjunctival epithelium. These molecules function to attract and retain inflammatory cells in the conjunctiva.

Upregulation of expression of HLA-DR and ICAM-1 has been reported in a variety of dry eye diseases, such as ocular rosacea, non-Sjögren's syndrome (SS) aqueous tear deficient and SS patients ${ }^{(33-36)}$, but the highest expression of HLA-DR was found in the conjunctival epithelium of SS patients ${ }^{(33,36)}$. Increased HLA-DR antigen expression by the conjunctival epithelium detected by flow cytometry has been observed as a universal feature of dry eye ${ }^{(37-38)}$.

\section{Role of $T$ cells}

Sjögren's syndrome is characterized by dry eyes, dry mouth, vasculitis and neurologic disease. The cardinal manifestation of SS is dryness, resulting from exocrine gland dysfunction. At the cellular level, the involved exocrine tissues (including the lacrimal gland) are infiltrated with lymphocytes, monocytes and plasma cells ${ }^{(39)}$. T cell infiltration of the conjunctiva has been observed in both SS and non-SS $\mathrm{KCS}^{(40-41)}$.

There is increased evidence that CD4+ T cells are involved in the pathogenesis of dry eye. In an animal model, increased infiltration of $\mathrm{CD} 4+\mathrm{T}$ cells in the goblet cell rich area was accompanied by increased expression of IFN-y, goblet cell loss and conjunctival metaplasia ${ }^{(17)}$. Inflammation in the lacrimal glands, cornea, and conjunctiva, resulting in decreased tear production and conjunctival goblet cell loss, was transferable from wild type mice subjected to experimental dry eye to T-cell-deficient nude mice that have not been exposed to desiccating stress ${ }^{(7)}$. Using a similar approach, $\mathrm{CD} 4+\mathrm{T}$ cells adoptively transferred from animals deficient in the autoimmune regulator (aire) gene to immunodeficient recipients mice caused advanced ocular surface keratinization $^{(42)}$.

\section{Anti-inflammatory therapy in dry eye}

Clinical evidence indicates that anti-inflammatory therapies that inhibit these inflammatory mediators reduce the signs and symptoms of keratoconjunctivis sicca (KCS). Our review will therefore focus on the current available antiinflammatory therapy of dry eye. 


\section{Corticosteroids}

Corticosteroids are potent anti-inflammatory agents that are routinely used to control inflammation in many organs. Corticosteroids have multiple mechanisms of action. They work through traditional glucocorticoid receptor mediated pathways to directly regulate gene expression and they also work through non-receptor pathways to interfere with transcriptional regulators of pro-inflammatory genes, such as NF$\mathrm{kB}$. Among their multiple biological activities, corticosteroids inhibit inflammatory cytokine and chemokine production, decrease the synthesis of matrix metalloproteinases and lipid mediators of inflammation (e.g. prostaglandins), decrease expression of cell adhesion molecules (e.g. ICAM-1) and stimulate lymphocyte apoptosis ${ }^{(43-48)}$. They have been reported to decrease the production of a number of inflammatory cytokines (IL-1, IL-6, IL-8, TNF- $\alpha$, GM-CSF) and MMP-9 by the corneal epithelium ${ }^{(49)}$.

Corticosteroids have been successfully used to treat the corneal epithelial disease in dry eye ${ }^{(50-52)}$ in several clinical studies. In a retrospective clinical series, topical administration of a $1 \%$ solution of non-preserved methylprednisolone, given 3-4 times daily for two weeks to patients with Sjögren syndrome KCS, provided moderate to complete relief of symptoms in all patients ${ }^{(51)}$. In addition, there was a decrease in corneal fluorescein staining and complete resolution of filamentary keratitis. This therapy was effective even for patients suffering from severe KCS who had no improvement with maximum aqueous enhancement therapies. In a prospective, randomized clinical trial, topical treatment of dry eye patients with non-preserved methylprednisolone and punctual plugs significantly decreased the severity of ocular irritation symptoms and corneal fluorescein staining compared to the group that received punctual occlusion alone ${ }^{(53)}$. No steroid related complications were observed in this study.

A randomized, double-masked, placebo-controlled study of loteprednol etabonate showed that a subset of patients with the most severe inflammatory signs at entry, treated topically with loteprednol, showed a significantly greater decrease in central corneal fluorescein staining scores when compared to its vehicle ( $31 \%$ vs. $0 \%$, respectively). There was also a significant decrease in inferior bulbar conjunctival hyperemia (25\%) in the loteprenol treated group compared to the vehicle treated group that had a $33 \%$ increase. There was no change in intraocular pressure in the steroid treated group.

In another open-label randomized study, patients with KCS that received fluorometholone plus artificial tear substitutes experienced lower symptom severity scores, fluorescein and rose bengal staining than either patients receiving either artificial tear substitute alone, or artificial tear substitute plus flurbiprofen ${ }^{(54)}$.

The corticosteroid methylprednisolone was noted to preserve corneal epithelial smoothness and barrier function in an experimental murine model of dry eye $\mathrm{e}^{(55)}$. This was attributed to its ability to maintain the integrity of corneal epithelial tight junctions and decrease desquamation of api- cal corneal epithelial cells (de Paiva et al. 2006) ${ }^{(55)}$. A concurrent study showed that methylprednisolone prevented an increase in MMP-9 protein in the corneal epithelium, as well as gelatinase activity in the corneal epithelium in response to experimental dry eye ${ }^{(29)}$

Taken together, these studies indicate that topical corticosteroids are an important tool in the management of dry eye. While no steroid related complications were observed in these short-term clinical trials, there is the potential for toxicity with long term use, such as increase on intraocular pressure and cataracts. This may limit the use of more potent steroids for chronic therapy of dry eye. The risk-benefit ratio may be better with "soft steroids" such as fluorometholone and loteprednol etabonate that have less intraocular activity and a lower likelihood of raising intraocular pressure.

\section{Cyclosporine}

Cyclosporine A (CsA) is a lipophilic cyclic undecapeptide isolated from the fungus Hypocladium inflatum gams $^{(56)}$. It was first introduced for clinical use in 1983, as an immunosuppressant drug to prevent organ rejection after transplant. The immunomodulatory effect of the drug has proved to be beneficial for treatment of a broad group of diseases that have in common an underlying inflammatory response in their pathophysiology (psoriasis, rheumatoid arthritis, ulcerative colitis, etc).

One of the mechanisms of action of CsA is the inhibition of calcineurin, (a serine/threonine phosphatase) with subsequent restriction in the expression of certain genes involved in T-cell activation (IL-2, IL-4, IL-12p40). CsA also can bind cyclophiline $\mathrm{D}$, and the complex formed can prevent the opening of the mitochondrial permeability transition pore in response to stress stimuli, thus preventing apoptosis. There is evidence that CsA blocks JNK and p38 signaling pathways as well and it has been shown to induce the synthesis of TGF- $\beta$ in vivo and in vitro ${ }^{(56)}$.

The potential of cyclosporine-A (CsA) for treating dry eye disease was initially recognized in dogs that develop spontaneous $\mathrm{KCS}^{(57)}$. Since the initial description, the therapeutic efficacy of CsA for human KCS has been well documented, with evidence ranging from several small single center randomized double-masked clinical trials to several large multicenter randomized, double-masked clinical trials ${ }^{(58-60)}$.

Two independent phase 3 clinical trials compared twice daily treatment with $0.05 \%$ or $0.1 \%$ CsA or vehicle in 877 patients with moderate to severe dry eye disease $\mathrm{e}^{(60-61)}$. When the results of the two phase 3 trials were combined for statistical analysis, patients treated with CsA, $0.05 \%$ or $0.1 \%$, showed significantly $(\mathrm{P} \leq 0.05)$ greater improvement in two objective signs of dry eye disease (corneal fluorescein staining and anesthetized Schirmer test values) than those treated with vehicle. An increased Schirmer test score was observed in $59 \%$ of patients treated with CsA, with $15 \%$ of patients having an increase of $10 \mathrm{~mm}$ or more. In contrast, only $4 \%$ of vehicle-treated patients had this magnitude of change in 
their Schirmer test scores $(\mathrm{P}<0.0001)$. CsA $0.05 \%$ treatment also produced significantly greater improvements $(\mathrm{P}<0.05)$ in three subjective measures of dry eye disease (blurred vision symptoms, need for concomitant artificial tears, and the global response to treatment). No dose-response effect was noted. Both doses of CSA exhibited an excellent safety profile with no significant systemic or ocular adverse events, except for transient burning symptoms after instillation in $17 \%$ of patients. Burning was reported in $7 \%$ of patients receiving the vehicle. No CsA was detected in the blood of patients treated with topical CsA for 12 months. Clinical improvement that was observed in these trials from CsA was accompanied by improvement in other disease parameters. Treated eyes had an approximately $200 \%$ increase in conjunctival goblet cell density ${ }^{(62)}$. Furthermore, there was decreased expression of immune activation markers (i.e. HLADR), apoptosis markers (i.e. Fas), and the inflammatory cytokine IL- 6 by the conjunctival epithelial cells ${ }^{(63-64)}$. The numbers of CD3, CD4, and CD8-positive T lymphocytes in the conjunctiva decreased in cyclosporine-treated eyes, while vehicle-treated eyes showed an increased number of cells expressing these markers ${ }^{(62)}$. Following treatment with $0.05 \%$ cyclosporine, there was a significant decrease in the number of cells expressing the lymphocyte activation markers CD11a and HLA-DR, indicating less activation of lymphocytes compared with vehicle-treated eyes.

Topical CsA significantly reduced conjunctival epithelial apoptosis and protected against goblet cell loss in experimental murine dry eye ${ }^{(65-66)}$, while reducing the number of CD4+ T cells infiltrating the conjunctiva. It also retained the intraepithelial lymphocyte population in the same area ${ }^{(66)}$.

In December 2002, the US Food and Drug Administration approved CsA $0.05 \%$ ophthalmic emulsion for treatment of dry eye disease and it has been a record number of prescriptions in the USA and worldwide.

\section{Tetracyclines and their derivatives}

The tetracyclines have anti-inflammatory as well as antibacterial properties that may make them useful for the management of chronic inflammatory diseases. These agents decrease the activity of collagenase, phospholipase A2, and several matrix metalloproteinases. They also decrease the production of IL- $1 \alpha$ and TNF- $\alpha$ in a wide range of tissues, including the corneal epithelium ${ }^{(67-69)}$. At high concentrations, tetracyclines inhibit staphylococcal exotoxin-induced cytokines and chemokines $^{(70-71)}$. Tetracyclines are also known to inhibit matrix metalloproteinase expression, suggesting a rationale for their use in ocular rosacea ${ }^{(72)}$. Tetracyclines can also inhibit angiogenesis, that may develop in benign conditions (e.g., rosacea) and malignant processes (e.g., cancer). Minocycline and doxycycline were found to inhibit angiogenesis induced by implanted tumors in rabbit cornea ${ }^{(73)}$.

Tetracyclines have been used extensively to treat rosacea ${ }^{(74-77)}$. Rosacea, including its ocular manifestations, is an inflammatory disorder, occurring mainly in adults with peak severity in the third and fourth decades. It is characterized by vasomotor instability (flushing) of the face, neck, and upper chest. Chronic facial inflammation may lead to persistent facial erythema and telangiectasia formation, and, ultimately, significant deformity of the central face. Current recommendations are to treat rosacea with long-term doxycycline, minocycline, tetracycline, or erythromycin. These recommendations may be tempered by certain recent reports that in women, the risk of developing breast cancer and breast cancer morbidity increases cumulatively with duration of antibiotic use, including tetracyclines ${ }^{78-79}$. Another large study did not substantiate these findings ${ }^{(80)}$.

The already mentioned anti-inflammatory effects of tetracycline may explain, at least in part, their beneficial effects in rosacea. Inhibition of angiogenesis may be a contributory factor in the therapeutic effect of tetracycline in this group of disorders. Factors that promote angiogenesis may contribute to the telangiectasia of rosacea. These include protease-triggered release of angiogenic factors stored in the extracellular matrix, inactivation of endothelial growth factor inhibitors, and release of angiogenic factors from activated macrophages ${ }^{(81-82)}$. Tetracycline derivatives (e.g. minocycline, doxycycline) have been recommended as treatment options for chronic blepharitis because of their high concentration in tissues, low renal clearance, long half-life, high level of binding to serum proteins, and decreased risk of photosensitization ${ }^{83)}$.

Doxycycline was discovered in the early 1960's as a semisynthetic long-acting tetracycline derivative useful as a bacterial ribosome inhibitor in a wide variety of microbes. In subantimicrobial doses it is also an effective primary treatment for rosacea, sterile corneal ulceration, and effective adjunctive treatment for adult periodontitis ${ }^{(84-86)}$. Doxycycline has been shown to effectively inhibit MMP-9 in a wide variety of mouse and human cells including prostate epithelium, epidermal keratinocytes, and the aortic endothelium ${ }^{(87-90)}$.

Previously reported studies using experimental dry eye model demonstrated that doxycycline was efficacious in decreasing gelatinolytic activity in the ocular surface epithelia, as well as decreasing levels of MMP-9 mRNA transcripts, and preventing experimental dry eye-induced increase in inflammatory cytokines IL-1 and TNF- $\alpha^{(29)}$. Doxycycline also improved corneal surface regularity and improved corneal barrier function ${ }^{(55)}$. At the cellular level, doxycycline preserved apical epithelial cell area and the tight-junction protein occludin, resulting in a decreased number of desquamating epithelial cells from the surface of the cornea ${ }^{(55,91)}$. These findings were also confirmed in cultured human corneal epithelial cells treated with doxycycline subjected to osmotic stress that increases their production of MMP-9(28).

A phase 3 FDA clinical trial is underway to evaluate the efficacy of a topical novel preparation of doxycycline in dry eye patients.

One randomized controlled clinical trial of tetracycline in ocular rosacea compared symptom improvement in 24 patients treated with either tetracycline or doxycycline ${ }^{(77)}$. All 
but one patient reported an improvement in symptoms after 6 weeks of therapy. No placebo group was included in this trial. A prospective, randomized, double-blind, placebo-controlled, partial crossover trial compared the effect of oxytetracycline to provide symptomatic relief of blepharitis with or without rosacea. Only $25 \%$ of the patients with blepharitis without rosacea responded to the antibiotic, whereas $50 \%$ responded when both diseases were present ${ }^{(92)}$. In another trial of 10 patients with both acne rosacea and concomitant meibomianitis, acne rosacea without concomitant ocular involvement, or seborrheic blepharitis, minocycline $50 \mathrm{mg}$ daily for 2 weeks followed by $100 \mathrm{mg}$ daily for a total of 3 months significantly decreased bacterial flora. Clinical improvement was seen in all patients with meibomianitis ${ }^{(93)}$.

Because of the improvement observed in small clinical trials of patients with meibomianitis, the American Academy of Ophthalmology recommends the chronic use of either doxycycline or tetracycline for the management meibomianitis ${ }^{(94)}$. Larger randomized placebo-controlled trials assessing symptom improvement rather than surrogate markers are needed to clarify the role of this antibiotic in blepharitis treatment ${ }^{(71)}$. Several studies have described the beneficial effects of minocycline and other tetracycline derivatives (e.g. doxycycline) in the treatment of chronic blepharitis ${ }^{(83,95-97)}$. Studies have shown significant changes in the aqueous tear parameters, such as tear volume and tear flow following treatment that with tetracycline derivatives (e.g. minocycline). One study also demonstrated a decrease in the aqueous tear production that occurred along with clinical improvement ${ }^{(98)}$.

The randomized prospective study by Yoo and colleagues $^{(99)}$ compared 2 different doxycycline doses $(200 \mathrm{mg}$ and $20 \mathrm{mg} /$ day) in patients who had chronic meibomian gland dysfunction and who did not respond to lid hygiene and topical therapy for more than 2 months. Both the high and low dose group had statistically significant improvement in TBUT after treatment. This implies that low dose doxycycline (20 mg twice a day) therapy may be effective in patients with chronic meibomian gland dysfunction.

\section{Essential fatty acids}

Essential fatty acids are necessary for complete health and they cannot be synthesized by vertebrates and must be obtained from dietary sources. Among the essential fatty acids are 18 carbon omega- 6 and omega- 3 fatty acids. In the typical western diet, 20-25 times more omega- 6 than omega-3 fatty acids are consumed. Omega- 6 fatty acids are precursors for arachidonic acid and certain pro-inflammatory lipid mediators ( $\mathrm{PGE}_{2}$ and LTB4). In contrast, certain omega-3 fatty acids (e.g. EPA found in fish oil) inhibit the synthesis of these lipid mediators as well as block production of IL-1 and TNFalpha $^{(100-101)}$. A beneficial clinical effect of fish oil omega-3 fatty acids on rheumatoid arthritis has been observed in several double-masked placebo-controlled clinical trials ${ }^{(102-103)}$. In a prospective placebo-controlled clinical trial of the essential fatty acids linoleic acid and gamma-linoleic acid admi- nistered orally twice daily produced significant improvement in ocular irritation symptoms and ocular surface lissamine green staining ${ }^{(104)}$. Decreased conjunctival HLA-DR staining also was observed.

In dry eye induced animal, topical treatment with alphalinolenic acid significantly decreased corneal fluorescein staining compared with both vehicle and untreated controls and decreased $\mathrm{CD} 11 \mathrm{~b}(+)$ cell number, expression of corneal IL- $1 \alpha$ and TNF- $\alpha$, and conjunctival TNF- $\alpha^{(105)}$.

\section{RESUMO}

Olho seco é uma doença multifatorial que resulta em disfunção da unidade lacrimal glandular. Evidências sugerem que inflamação está involvida na patogênese da doença. Mudanças na composição das lágrimas, incluindo aumento de citocinas, quimiocinas, metaloproteinases e o número de células $\mathrm{T}$ na conjuntiva são encontrados em pacientes com olho seco e em modelos animais. Esta inflamação é responsável em parte pelos sintomas de irritação, doença epitelial de surperfície ocular e função epitelial de barreira alterada em olho seco. Existem várias terapias antiinflamatórias que se direcionam para um ou mais mediadores/vias que foram identificados e são discutidos em detalhe.

Descritores: Síndromes do olho seco; Inflamação; Concentração osmolar; Ciclosporina/uso terapêutico; Doxiciclina/ uso terapêutico; Citocinas/uso terapêutico; Metaloproteases; Antiinflamatórios/uso terapêutico

\section{REFERENCES}

1. Pflugfelder SC, Tseng SC, Sanabria O, Kell H, Garcia CG, Felix C et al. Evaluation of subjective assessments and objective diagnostic tests for diagnosing tear-film disorders known to cause ocular irritation. Cornea. 1998;17(1):38-56.

2. Musch DC, Sugar A, Meyer RF. Demographic and predisposing factors in corneal ulceration. Arch Ophthalmol. 1983;101(10):1545-8.

3. de Paiva CS, Lindsey JL, Pflugfelder SC. Assessing the severity of keratitis sicca with videokeratoscopic indices. Ophthalmology. 2003;110(6):1102-9.

4. Goto E, Yagi Y, Matsumoto Y, Tsubota K. Impaired functional visual acuity of dry eye patients. Am J Ophthalmol. 2002;133(2):181-6.

5. Miljanoviæ B, Dana R, Sullivan DA, Schaumberg DA. Impact of dry eye syndrome on vision-related quality of life. Am J Ophthalmol. 2007;143(3): 409-15.

6. Luo L, Li DQ, Doshi A, Farley W, Corrales RM, Pflugfelder SC. Experimental dry eye stimulates production of inflammatory cytokines and MMP-9 and activates MAPK signaling pathways on the ocular surface. Invest Ophthalmol Vis Sci. 2004;45(12):4293-301.

7. Niederkorn JY, Stern ME, Pflugfelder SC, De Paiva CS, Corrales RM, Gao $\mathrm{J}$ et al. Desiccating stress induces T cell-mediated Sjögren's Syndrome-like lacrimal keratoconjunctivitis. J Immunol. 2006;176(7):3950-7.

8. Zhu X, Topouzis S, Liang LF, Stotish RL. Myostatin signaling through Smad2, Smad3 and Smad4 is regulated by the inhibitory Smad7 by a negative feedback mechanism. Cytokine. 2004;26(6):262-72.

9. López Bernal D, Ubels JL Quantitative evaluation of the corneal epithelial barrier: effect of artificial tears and preservatives. Curr Eye Res. 1991;10(7): 645-56.

10. Lopez Bernal D, Ubels JL. Artificial tear composition and promotion of recovery of the damaged corneal epithelium. Cornea. 1993;12(2):115-20. 
11. Jones DT, Monroy D, Ji Z, Atherton SS, Pflugfelder SC. Sjögren's syndrome: cytokine and Epstein-Barr viral gene expression within the conjunctival epithelium. Invest Ophthalmol Vis Sci. 1994;35(9):3493-504.

12. Pflugfelder SC, Jones D, Ji Z, Afonso A, Monroy D. Altered cytokine balance in the tear fluid and conjunctiva of patients with Sjögren's syndrome keratoconjunctivitis sicca. Curr Eye Res. 1999;19(3):201-11.

13. Solomon A, Dursun D, Liu Z, Xie Y, Macri A, Pflugfelder SC. Pro- and antiinflammatory forms of interleukin-1 in the tear fluid and conjunctiva of patients with dry-eye disease. Invest Ophthalmol Vis Sci. 2001;42(10):2283-92.

14. Stern ME, Gao J, Schwalb TA, Ngo M, Tieu DD, Chan CC et al. Conjunctival T-cell subpopulations in Sjögren's and non-Sjögren's patients with dry eye. Invest Ophthalmol Vis Sci. 2002;43(8):2609-14.

15. Baudouin C, Liang H, Bremond-Gignac D, Hamard P, Hreiche R, CreuzotGarcher $\mathrm{C}$ et al. CCR 4 and CCR 5 expression in conjunctival specimens as differential markers of $\mathrm{T}(\mathrm{H}) 1 / \mathrm{T}(\mathrm{H}) 2$ in ocular surface disorders. J Allergy Clin Immunol. 2005;116(3):614-9.

16. Rolando M, Barabino S, Mingari C, Moretti S, Giuffrida S, Calabria G. Distribution of conjunctival HLA-DR expression and the pathogenesis of damage in early dry eyes. Cornea. 2005;24(8):951-4.

17. De Paiva CS, Villarreal AL, Corrales RM, Rahman HT, Chang VY, Farley WJ et al. Dry eye-induced conjunctival epithelial squamous metaplasia is modulated by interferon-gamma. Invest Ophthalmol Vis Sci. 2007;48(6):2553-60.

18. Yoon KC, Jeong IY, Park YG, Yang SY. Interleukin-6 and tumor necrosis factor-alpha levels in tears of patients with dry eye syndrome. Cornea. 2007; 26(4):431-7.

19. Corrales RM, Villarreal A, Farley W, Stern ME, Li DQ, Pflugfelder SC. Strainrelated cytokine profiles on the murine ocular surface in response to desiccating stress. Cornea. 2007;26(5):579-84.

20. Farris RL. Tear osmolarity-a new gold standard? Adv Exp Med Biol. 1994;350:495-503.

21. Noecker R. Effects of common ophthalmic preservatives on ocular health. Adv Ther. 2001;18(5):205-15.

22. Tripathi BJ, Tripathi RC, Kolli SP. Cytotoxicity of ophthalmic preservatives on human corneal epithelium. Lens Eye Toxic Res. 1992;9(3-4): 361-75.

23. Nelson JD, Drake MM, Brewer JT Jr, Tuley M. Evaluation of a physiological tear substitute in patients with keratoconjunctivitis sicca. Adv Exp Med Biol. 1994;350:453-7.

24. Li D-Q, Chen Z, Song XJ, Farley W, Pflugfelder SC. Hyperosmolarity stimulates production of MMP-9, IL-1b and TNF- by human corneal epithelial cells via a c-Jun $\mathrm{NH}_{2}$ terminal kinase pathway [abstract]. Invest Ophthalmol Vis Sci. 2002;43. EAbstract 1981.

25. Annesley WH Jr, Augsburger JJ, Shakin JL. Ten year follow-up of photocoagulated central serous choroidopathy. Trans Am Ophthalmol Soc. 1981;79: 335-46.

26. Afonso AA, Sobrin L, Monroy DC, Selzer M, Lokeshwar B, Pflugfelder SC. Tear fluid gelatinase B activity correlates with IL-1alpha concentration and fluorescein clearance in ocular rosacea. Invest Ophthalmol Vis Sci. 1999;40(11):2506-12.

27. Sobrin L, Liu Z, Monroy DC, Solomon A, Selzer MG, Lokeshwar BL et al. Regulation of MMP-9 activity in human tear fluid and corneal epithelial culture supernatant. Invest Ophthalmol Vis Sci. 2000;41(7):1703-9.

28. Pflugfelder SC, Farley W, Luo L, Chen LZ, de Paiva CS, Olmos LC et al. Matrix metalloproteinase-9 knockout confers resistance to corneal epithelial barrier disruption in experimental dry eye. Am J Pathol. 2005;166(1):61-71.

29. De Paiva CS, Corrales RM, Villarreal AL, Farley WJ, Li DQ, Stern ME et al. Corticosteroid and doxycycline suppress MMP-9 and inflammatory cytokine expression, MAPK activation in the corneal epithelium in experimental dry eye. Exp Eye Res. 2006;83(3):526-35.

30. Chotikavanich S, Li DQ, de Paiva CS, Bian F, Farley JW, Pflugfelder SC. Tear MMP-9 activity in dysfunctional tear syndrome [abstract]. Invest Ophthalmol Vis Sci 2008; 49: E-Abstract 5293.

31. Mrugacz M, Zelazowska B, Bakunowicz-Lazarczyk A, Kaczmarski M, Wysocka J. Elevated tear fluid levels of MIP-1alpha in patients with cystic fibrosis. J Interferon Cytokine Res. 2007;27(6):491-5.

32. Yoon KC, De Paiva CS, Qi H, Chen Z, Farley WJ, Li DQ, et al. Expression of Th-1 chemokines and chemokine receptors on the ocular surface of C57BL/6 mice: effects of desiccating stress. Invest Ophthalmol Vis Sci. 2007;48(6):2561-9.

33. Tsubota K, Fukagawa K, Fujihara T, Shimmura S, Saito I, Saito K, et al. Regulation of human leukocyte antigen expression in human conjunctival epithelium. Invest Ophthalmol Vis Sci. 1999;40(1):28-34.
34. Tsubota K, Fujihara T, Saito K, Takeuchi T. Conjunctival epithelium expression of HLA-DR in dry eye patients. Ophthalmologica. 1999;213(1):16-9.

35. Pisella PJ, Brignole F, Debbasch C, Lozato PA, Creuzot-Garcher C, Bara J, et al. Flow cytometric analysis of conjunctival epithelium in ocular rosacea and keratoconjunctivitis sicca. Ophthalmology. 2000;107(10):1841-9.

36. Brignole F, Pisella PJ, Goldschild M, De Saint JM, Goguel A, Baudouin C. Flow cytometric analysis of inflammatory markers in conjunctival epithelial cells of patients with dry eyes. Invest Ophthalmol Vis Sci. 2000;41:1356-63.

37. Baudouin C, Brignole F, Pisella PJ, De Jean MS, Goguel A. Flow cytometric analysis of the inflammatory marker HLA DR in dry eye syndrome: results from 12 months of randomized treatment with topical cyclosporin A. Adv Exp Med Biol. 2002;506(Pt B):761-9.

38. Brignole F, Pisella PJ, Goldschild M, De Saint Jean M, Goguel A, Baudouin C. Flow cytometric analysis of inflammatory markers in conjunctival epithelial cells of patients with dry eyes. Invest Ophthalmol Vis Sci. 2000;41(6):1356-63.

39. Carsons S. A review and update of Sjögren's syndrome: manifestations, diagnosis, and treatment. Am J Manag Care. 2001;7(14 Suppl):S433-43.

40. Pflugfelder SC, Huang AJ, Feuer W, Chuchovski PT, Pereira IC, Tseng SC. Conjunctival cytologic features of primary Sjögren's syndrome. Ophthalmology. 1990;97(8):985-91

41. Raphael M, Bellefqih S, Piette JC, Le Hoang P, Debre P, Chomette G. Conjunctival biopsy in Sjögren's syndrome: correlations between histological and immunohistochemical features. Histopathology. 1988;13(2): 191-202.

42. Li S, Nikulina K, DeVoss J, Wu AJ, Strauss EC, Anderson MS et al. Small proline-rich protein 1B (SPRR1B) is a biomarker for squamous metaplasia in dry eye disease. Invest Ophthalmol Vis Sci. 2008;49(1):34-41.

43. Solomon A, Rosenblatt M, Li D, Monroy D, Ji Z, Lokeshwar BL et al. Doxycycline inhibition of interleukin-1 in the corneal epithelium. Am J Ophthalmol. 2000;130(5):688.

44. Hashimoto S, Gon Y, Matsumoto K, Takeshita I, Maruoka S, Horie T. Inhalant corticosteroids inhibit hyperosmolarity-induced, and cooling and rewarming-induced interleukin- 8 and RANTES production by human bronchial epithelial cells. Am J Respir Crit Care Med. 2000;162(3 Pt 1): 1075-80.

45. Dursun D, Kim MC, Solomon A, Pflugfelder SC. Treatment of recalcitrant recurrent corneal erosions with inhibitors of matrix metalloproteinase-9, doxycycline and corticosteroids. Am J Ophthalmol. 2001;132(1):8-13.

46. Liden J, Rafter I, Truss M, Gustafsson JA, Okret S. Glucocorticoid effects on NF-kappaB binding in the transcription of the ICAM-1 gene. Biochem Biophys Res Commun. 2000;273(3):1008-14.

47. Aksoy MO, Li X, Borenstein M, Yi Y, Kelsen SG. Effects of topical corticosteroids on inflammatory mediator-induced eicosanoid release by human airway epithelial cells. J Allergy Clin Immunol. 1999;103(6):1081-91.

48. Brunner T, Arnold D, Wasem C, Herren S, Frutschi C. Regulation of cell death and survival in intestinal intraepithelial lymphocytes. Cell Death Differ. 2001;8(7):706-14.

49. Djalilian AR, Nagineni CN, Smith JA, Nussenblatt RB, Hooks JJ. Effects of dexamethasone and cyclosporine $\mathrm{A}$ on the production of cytokines by human corneal epithelial cells and fibroblasts [abstract]. Invest Ophthalmol Vis Sci. 2001 [Presented at ARVO Abstracts; 2001].

50. Pflugfelder SC, Maskin SL, Anderson B, Chodosh J, Holland EJ, De Paiva $\mathrm{CS}$ et al. A randomized, double-masked, placebo-controlled, multicenter comparison of loteprednol etabonate ophthalmic suspension, $0.5 \%$, and placebo for treatment of keratoconjunctivitis sicca in patients with delayed tear clearance. Am J Ophthalmol. 2004;138(3):444-57.51.

51. Marsh P, Pflugfelder SC. Topical nonpreserved methylprednisolone therapy for keratoconjunctivitis sicca in Sjögren syndrome. Ophthalmology. 1999; 106(4):811-6.

52. Wachtel M, Frei K, Ehler E, Fontana A, Winterhalter K, Gloor SM. Occludin proteolysis and increased permeability in endothelial cells through tyrosine phosphatase inhibition. J Cell Sci. 1999;112 (Pt 23):4347-56.

53. Sainz De La Maza Serra M, Simón Castellvi C, Kabbani O. [Nonpreserved topical steroids and lacrimal punctal occlusion for severe keratoconjunctivitis sicca]. Arch Soc Esp Oftalmol. 2000;75(11):751-756. Spanish.

54. Avunduk AM, Avunduk MC, Varnell ED, Kaufman HE. The comparison of efficacies of topical corticosteroids and nonsteroidal anti-inflammatory drops on dry eye patients: a clinical and immunocytochemical study. Am J Ophthalmol. 2003;136(4):593-602.

55. De Paiva CS, Corrales RM, Villarreal AL, Farley W, Li DQ, Stern ME et al. Apical corneal barrier disruption in experimental murine dry eye is abrogated by methylprednisolone and doxycycline. Invest Ophthalmol Vis Sci. 2006;47(7):2847-56. 
56. Matsuda S, Koyasu S. Mechanisms of action of cyclosporine. Immunopharmacology. 2000;47(2-3):119-25.

57. Kaswan RL, Salisbury MA, Ward DA. Spontaneous canine keratoconjunctivitis sicca. A useful model for human keratoconjunctivitis sicca: treatment with cyclosporine eye drops. Arch Ophthalmol. 1989;107(8):1210-6.

58. Gündüz K, Ozdemir O. Topical cyclosporin treatment of keratoconjunctivitis sicca in secondary Sjögren's syndrome. Acta Ophthalmol (Copenh). 1994;72 (4):438-42.

59. Laibovitz RA, Solch S, Andriano K, O'Connell M, Silverman MH. Pilot trial of cyclosporine $1 \%$ ophthalmic ointment in the treatment of keratoconjunctivitis sicca. Cornea. 1993;12(4):315-23.

60. Stevenson D, Tauber J, Reis BL. Efficacy and safety of cyclosporin A ophthalmic emulsion in the treatment of moderate-to-severe dry eye disease: a dose-ranging, randomized trial. The Cyclosporin A Phase 2 Study Group. Ophthalmology. 2000;107(5):967-74.

61. Sall K, Stevenson OD, Mundorf TK, Reis BL. Two multicenter, randomized studies of the efficacy and safety of cyclosporine ophthalmic emulsion in moderate to severe dry eye disease. CsA Phase 3 Study Group. Ophthalmology. 2000;107(4):631-9.

62. Kunert KS, Tisdale AS, Gipson IK. Goblet cell numbers and epithelial proliferation in the conjunctiva of patients with dry eye syndrome treated with cyclosporine. Arch Ophthalmol. 2002;120(3):330-7.

63. Brignole F, Pisella PJ, De Saint Jean M, Goldschild M, Goguel A, Baudouin C. Flow cytometric analysis of inflammatory markers in KCS: 6month treatment with topical cyclosporin A. Invest Ophthalmol Vis Sci. 2001;42(1):90-5.

64. Turner K, Pflugfelder SC, Ji Z, Feuer WJ, Stern M, Reis BL. Interleukin-6 levels in the conjunctival epithelium of patients with dry eye disease treated with cyclosporine ophthalmic emulsion. Cornea. 2000;19(4):492-6.

65. Strong B, Farley W, Stern ME, Pflugfelder SC. Topical cyclosporine inhibits conjunctival epithelial apoptosis in experimental murine keratoconjunctivitis sicca. Cornea. 2005;24(1):80-5.

66. Pangelinan SB, de Paiva CS, Singh R, et al. Topical Cyclosporine Emulsion Modulates Immune Response in Experimental Dry Eye [abstract]. Invest Ophthalmol Vis Sci. 2008;49:440.

67. Solomon A, Rosenblatt M, Li DQ, Liu Z, Monroy D, Ji Z et al. Doxycycline inhibition of interleukin-1 in the corneal epithelium. Invest Ophthalmol Vis Sci. 2000;41(9):2544-57.

68. Li DQ, Luo L, Chen Z, Kim HS, Song XJ, Pflugfelder SC. JNK and ERK MAP kinases mediate induction of IL-1beta, TNF-alpha and IL-8 following hyperosmolar stress in human limbal epithelial cells. Exp Eye Res. 2006;82 (4):588-96.

69. Li Y, Kuang K, Yerxa B, Wen Q, Rosskothen H, Fischbarg J. Rabbit conjunctival epithelium transports fluid, and P2Y2(2) receptor agonists stimulate Cl(-) and fluid secretion. Am J Physiol Cell Physiol. 2001;281(2): C595-602.

70. Krakauer T, Buckley M. Doxycycline is anti-inflammatory and inhibits staphylococcal exotoxin-induced cytokines and chemokines. Antimicrob Agents Chemother. 2003;47(11):3630-3.

71. Voils SA, Evans ME, Lane MT, Schosser RH, Rapp RP. Use of macrolides and tetracyclines for chronic inflammatory diseases. Ann Pharmacother. 2005;39(1):86-94.

72. Stone DU, Chodosh J. Oral tetracyclines for ocular rosacea: an evidencebased review of the literature. Cornea. 2004;23(1):106-9.

73. Tamargo RJ, Bok RA, Brem H. Angiogenesis inhibition by minocycline Cancer Res. 1991;51(2):672-5.

74. Macdonald A, Feiwel M. Perioral dermatitis: aetiology and treatment with tetracycline. Br J Dermatol. 1972;87(4):315-9.

75. Dursun D, Piniella AM, Pflugfelder SC. Pseudokeratoconus caused by rosacea. Cornea. 2001;20(6):668-9.

76. Jansen T, Plewig G. Rosacea: classification and treatment. J R Soc Med. 1997;90(3):144-50.

77. Frucht-Pery J, Chayet AS, Feldman ST, Lin S, Brown SI. The effect of doxycycline on ocular rosacea. Am J Ophthalmol. 1989;107(4):434-5.

78. Velicer CM, Heckbert SR, Lampe JW, Potter JD, Robertson CA, Taplin SH. Antibiotic use in relation to the risk of breast cancer. JAMA. 2004; 291(7): 827-35.

79. Velicer CM, Heckbert SR, Rutter C, Lampe JW, Malone K. Association between antibiotic use prior to breast cancer diagnosis and breast tumour characteristics (United States). Cancer Causes Control. 2006;17(3):307-13.
80. García Rodríguez LA, González-Pérez A. Use of antibiotics and risk of breast cancer. Am J Epidemiol. 2005;161(7):616-9.

81. Sapadin AN, Fleischmajer R. Tetracyclines: nonantibiotic properties and their clinical implications. J Am Acad Dermatol. 2006;54(2):258-65.

82. Wilkin JK. Rosacea. Pathophysiology and treatment. Arch Dermatol. 1994; 130(3):359-62.

83. Hoeprich PD, Warshauer DM. Entry of four tetracyclines into saliva and tears. Antimicrob Agents Chemother. 1974;5(3):330-6.

84. Akpek EK, Merchant A, Pinar V, Foster CS. Ocular rosacea: patient characteristics and follow-up. Ophthalmology. 1997;104(11):1863-7.

85. Seedor JA, Perry HD, McNamara TF, Golub LM, Buxton DF, Guthrie DS. Systemic tetracycline treatment of alkali-induced corneal ulceration in rabbits. Arch Ophthalmol. 1987;105(2):268-71.

86. Caton JG, Ciancio SG, Blieden TM, Bradshaw M, Crout RJ, Hefti AF et al. Treatment with subantimicrobial dose doxycycline improves the efficacy of scaling and root planing in patients with adult periodontitis. J Periodontol. 2000;71(4):521-32.

87. Lokeshwar BL. MMP inhibition in prostate cancer. Ann N Y Acad Sci. 1999;878:271-89.

88. Hanemaaijer R, Visser H, Koolwijk P, Sorsa T, Salo T, Golub LM et al. Inhibition of MMP synthesis by doxycycline and chemically modified tetracyclines (CMTs) in human endothelial cells. Adv Dent Res. 1998;12(2):114-8.

89. Hanemaaijer R, Sorsa T, Konttinen YT, Ding Y, Sutinen M, Visser H et al. Matrix metalloproteinase- 8 is expressed in rheumatoid synovial fibroblasts and endothelial cells. Regulation by tumor necrosis factor-alpha and doxycycline. J Biol Chem. 1997;272(50):31504-9.

90. Qin X, Corriere MA, Matrisian LM, Guzman RJ. Matrix metalloproteinase inhibition attenuates aortic calcification. Arterioscler Thromb Vasc Biol. 2006;26(7):1510-6.

91. Beardsely RM, de Paiva CS, Power DF, Pflugfelder SC. The protease inhibitor doxycycline preserves apical corneal epithelial integrity during desiccating stress. Cornea. In press 2008

92. Seal DV, Wright P, Ficker L, Hagan K, Troski M, Menday P. Placebo controlled trial of fusidic acid gel and oxytetracycline for recurrent blepharitis and rosacea. Br J Ophthalmol. 1995;79(1):42-5.

93. Ta CN, Shine WE, McCulley JP, Pandya A, Trattler W, Norbury JW. Effects of minocycline on the ocular flora of patients with acne rosacea or seborrheic blepharitis. Cornea. 2003;22(6):545-8.

94. McCulley JP, Dougherty JM, Deneau DG. Classification of chronic blepharitis. Ophthalmology. 1982;89(10):1173-80.

95. Shine WE, McCulley JP, Pandya AG. Minocycline effect on meibomian gland lipids in meibomianitis patients. Exp Eye Res. 2003;76(4):417-20.

96. Dougherty JM, McCulley JP, Silvany RE, Meyer DR. The role of tetracycline in chronic blepharitis. Inhibition of lipase production in staphylococci. Invest Ophthalmol Vis Sci. 1991;32(11):2970-5.

97. Gulbenkian A, Myers J, Fries D. Hamster flank organ hydrolase and lipase activity. J Invest Dermatol. 1980;75(4):289-92.

98. Aronowicz JD, Shine WE, Oral D, Vargas JM, McCulley JP. Short term oral minocycline treatment of meibomianitis. Br J Ophthalmol. 2006;90(7):856-60.

99. Yoo SE, Lee DC, Chang MH. The effect of low-dose doxycycline therapy in chronic meibomian gland dysfunction. Korean J Ophthalmol. 2005;19(4):258-63.

100. James MJ, Gibson RA, Cleland LG. Dietary polyunsaturated fatty acids and inflammatory mediator production. Am J Clin Nutr. 2000;71(1 Suppl): $343 \mathrm{~S}-8 \mathrm{~S}$.

101. Endres S, Ghorbani R, Kelley VE, Georgilis K, Lonnemann G, van der Meer JW et al. The effect of dietary supplementation with n-3 polyunsaturated fatty acids on the synthesis of interleukin-1 and tumor necrosis factor by mononuclear cells. N Engl J Med. 1989;320(5):265-71.

102. James MJ, Cleland LG. Dietary n-3 fatty acids and therapy for rheumatoid arthritis. Semin Arthritis Rheum. 1997;27(2):85-97.

103. Kremer JM. n-3 fatty acid supplements in rheumatoid arthritis. Am J Clin Nutr. 2000;71(1 Suppl):349S-51S.

104. Barabino S, Rolando M, Camicione P, Ravera G, Zanardi S, Giuffrida S et al. Systemic linoleic and gamma-linolenic acid therapy in dry eye syndrome with an inflammatory component. Cornea. 2003;22(2):97-101.

105. Rashid S, Jin Y, Ecoiffier T, Barabino S, Schaumberg DA, Dana MR. Topical omega-3 and omega- 6 fatty acids for treatment of dry eye. Arch Ophthalmol. 2008;126(2):219-25. 